\author{
Izabela Łuc \\ Zakład Dydaktyki i Pedagogiki Wczesnoszkolnej i Przedszkolnej \\ Uniwersytetu Śląskiego w Katowicach
}

\title{
Gwarowy leksem gryfny jako modny komponent kultury konsumpcyjnej
}

\section{Wprowadzenie}

Kultura konsumpcji ujmowana przez niektórych badaczy jako kultura wyzwolenia [por. Szlendak, Pietrowicz 2005: 85-108] ustanawia swoiste wzorce wyobrażeń na temat miejsca i roli człowieka w złożonym procesie globalnej egzystencji. Tworzone w jej przestrzeni teksty w sposób widoczny eksponują ponowoczesne tendencje do waloryzacji wytworów konsumpcji oraz grupy docelowej odbiorców, którzy traktowani są w komunikacyjnym modelu jako ogniwo machiny podaży i popytu. W obrębie perswazyjnych zachowań skupionych na odbiorcy tworzy się rozmaite typy komercyjnych wypowiedzi operujących określonym (dostosowanym do intencji komunikacyjnej i nastawionym na efekt) (sub)kodem porozumienia uwzględniającym charakter przyjętych koncepcji (pragmatycznych założeń) oraz sposobów interakcji. Spośród kreowanych tekstów na szczególną uwagę zasługują komunikaty reklamujące oferty i jakość świadczenia usług, w których obręb wprzęga się słownictwo gwarowe, swoiste dla regionu geograficznego, będące obiektem zainteresowania zleceniodawców kampanii reklamowych w celu pozyskania lokalnego odbiorcy. Jak dowodzi praktyka konsumpcyjna nadawców tekstów omawianego typu, działania te dzięki wyzyskaniu leksykalnych znaczeń i ich modyfikacji nazwać można metaforycznie

semiotycznym polem bitwy, na którym rozgrywa się walka między siłami inkorporacji a siłami sprzeciwu, między narzuconym zbiorem znaczeń, upodobań i tożsamości społecznych a znaczeniami, upodobaniami i tożsamościami społecznymi wyrażanymi w aktach semiotycznego sprzeciwu. [Storey 2003: 32]. 
Twórcy tekstów kultury, wyzyskując autoteliczną wartość gwary jako sposobu porozumiewania się członków mikrowspólnoty, generują nowe kontekstualnie konstytuowane i przemycane znaczenia. Owe operacje tekstowe umożliwiają osiąganie zamierzonego efektu przekładającego się na konsumpcyjne zachowania odbiorców oraz rozszerzanie repertuaru polszczyzny o nową, konsumpcyjną odmianę. Kreowane w ten sposób komercyjne wypowiedzi nie tylko przykuwają uwagę lokalnych odbiorców, ale na podstawie swoistego (opartego na zaufaniu i imitacji utożsamiania się z grupą docelową odbiorców) typu przekazu wzmacniają jego wiarygodność. Na tej płaszczyźnie komunikacyjnej dochodzi do rozszerzenia znaczeń leksyki wywodzącej się z gwary, wpisywanej kontekstualnie w inicjowany przekaz. Użyta strategia zezwala na mieszanie się w jej obrębie stylów komunikacji i gatunków wypowiedzi oraz na tworzenie zaskakujących kolokacji wyrazowych podlegających procesowi kompilacji intencjonalnie dobranych jednostek językowych, ułatwiających opis, wartościowanie i promocję produktów czy oferowanych usług.

Przedmiotem przyjętej tu analizy są sposoby tworzenia reklamowych wypowiedzi oraz struktur nazewniczych, w których formalnym wykładnikiem jest leksem gwarowy gryfny uznany za modny komponent polszczyzny konsumpcyjnej [zob. Ożóg 2004: 196-215]. Przy użyciu słowa gryfny wyróżnia się produkty, identyfikuje obiekty świadczące usługi lub punkty handlowe oferujące określony asortyment produktów. Marketingowo wyzyskane cechy i właściwości modnego leksemu nie tylko waloryzują produkt czy świadczoną usługę, ale jednocześnie wartościują użytkowników języka zamieszkujących Górny Śląsk. Dokonanej tu analizie przypisano kilka przenikających się celów badawczych. Po pierwsze, założono, że umożliwi ona odsłonę znaczenia komponentu gwarowego gryfny dla kultury i polszczyzny konsumpcyjnej, po drugie, ułatwi szczegółowy opis jego zmian znaczeniowych oraz (kon)tekstowej funkcjonalności, łącznie z deszyfracją perswazyjnych mechanizmów, za pomocą których nadawcy reklamowych wypowiedzi i twórcy nazw użytkowych (chrematonimów marketingowych, społecznościowych, ideacyjnych) wprowadzają w przestrzeń komunikatu swoisty dla odmiany gwarowej kod.

Materiał analityczny, pochodzący z reklam rozpowszechnianych przez media $\mathrm{i}$ internet w latach 2015-2019 oraz będący zapisem obserwacji regionalnej rzeczywistości komunikacyjnojęzykowej, odpowiednio pogrupowano, a dokonując jego selekcji, wzięto pod uwagę perswazyjne wypowiedzi i nazwy marketingowe, w których strukturę kontekstualnie wpisano modne słowo ${ }^{1}$

1 Używając sformułowania modny komponent (mając tu na myśli gwarowy leksem), uwzględniam szczególne eksponowanie owego słowa, wyrażające się w częstotliwości użycia. 
gryfny. Materiał reklamowy i nazewniczy opisano z perspektywy lingwistyki kulturowej i pragmalingwistyki; odwołano się również do strukturalistycznej koncepcji badawczej (teorii pól znaczeniowych), uwzględniając właściwe dla skompilowanej metodologii rozwiązania oraz złożony polisystem komercyjnych uwarunkowań. Opisywany tu problem zaprezentowano w czterech dopełniających się treściowo blokach tematycznych: znaczenie modnych słów w kulturze i polszczyźnie konsumpcyjnej; leksem gryfny w komunikacji górnośląskiej mikrowspólnoty; gryfny jako komponent reklamowych przekształceń; gryfny jako komercyjny wykładnik chrematonimii użytkowej. Założono, że ów sposób prezentacji umożliwi pełną odsłonę złożonego procesu wprzęgania w zasób polszczyzny konsumpcyjnej leksyki wywodzącej się z potocznej odmiany języka (gwary).

\section{Znaczenie modnych słów w kulturze i polszczyźnie konsumpcyjnej}

Kazimierz Ożóg wyraża pogląd, że modne wyrazy, wyrażenia oraz frazy zawierające komponent semantyczny 'duże natężenie danej cechy, dodatnie wartościowanie, maksimum czegoś', pojawiające się powszechnie w obsługującej sferę reklamy i handlu współczesnej polszczyźnie konsumpcyjnej, „oddają skłonność współczesnej kultury do wyrażania ekstremów" [Ożóg 2004: 95]. Wkomponowane w komercyjną wypowiedź modne słowa współtworzą odpowiednio skonfigurowany przekaz, „,modelujący siatkę oddziaływania perswazyjnego" [Loewe 2004: 34]. Owe komercyjne tendencje są wyrazem świadomości nadawców, że „[w]yrazy modne wydają się użytkownikom języka lepsze, ładniejsze, oryginalniejsze, atrakcyjniejsze od innych, sygnalizują w ich mniemaniu przynależność do określonego środowiska" [Kołodziejek 2006: 220].

W marketingowym wartościowaniu szczególną rolę odgrywają przymiotniki, które ze względu na swoje cechy i właściwości (impresywnie obrazują, mają gradacyjną moc i efektywnie wartościują - por. Laskowska 2008: 219-226) są doskonałym narzędziem, perswazyjnym operatorem pełniącym funkcję fatyczną na linii nadawca - odbiorca oraz pragmatycznym wykładnikiem stymulującym proces semantycznej (kontekstualnej) interpretacji. Przy użyciu przymiotników jako perswazyjnych komponentów reklamowych możliwe staje się dotarcie do językowej konceptualizacji świata i wartości odbiorców, na których podstawie buduje się iluzoryczne relacje bliskości z odbiorcą; tym samym zapisują się one w jego pamięci jako niekwestionowana konieczność skorzystania z oferowanej promocji czy usługi. W procesie marketingowej waloryzacji istotne znaczenie odgrywają też przysłówki (pochodne od przymiotników uznawanych za atrakcyjne narzędzie wartościowania), za 
pomocą których oddaje się jakość i moc produktów oraz ocenia się świadczone usługi. Przysłówki „opisują i oceniają towar, konkretyzują wyobrażenia o nim, a ponadto w stopniu większym niż inne wyrazy mają zdolność budzenia emocji u innych" [Kniagininowa, Pisarek 1965: 69]. Mają przy tym naturalną zdolność do predykacji i zwiększania dynamizmu wypowiedzi, scalając tekst i doskonale sprawdzając się w zdaniach eliptycznych. Występujące w tekstach kultury przymiotniki i przysłówki (najczęściej w stopniu wyższym i najwyższym) nazywane przez teoretyków reklamy trigger words 'słowa cynglowe' [Pisarek 1994: 65-74] wiążą się z konkretnym atrybutem produktu lub świadczonej usługi, przywołującym konotację pozytywną. Owe cynglowe słowa mają właściwości kontekstualnych modyfikacji - można dowolnie przekształcać ich znaczenia, wzbogacając je o nowy komercyjny semantyczny składnik wyrazu.

Twórcy komercyjnych tekstów kultury świadomi cech i właściwości kontekstualnego wyzyskiwania modnych słów mają nieograniczoną możliwość prowadzenia w ich obrębie gier komunikacyjnojęzykowych z odbiorcą [Łuc 2010: 175]. Dzięki modnym słowom, które w pragmatyce komercyjnej okazują się mieć uniwersalną moc (dopasowują się do kontekstu i ewokują pożądane znaczenia), stają się one popularnym ekwiwalentem komunikowania upowszechnianym za pomocą oficjalnych kanałów (medialnych). Popularyzowane w języku promocji i reklamy słowa wywodzące się z rozmaitych odmian języka (oficjalnego, slangu, gwary), dobierane pod kątem adresata, do którego kieruje się komunikat, nie tylko wzbogacają treściowo znaczenia w ponowoczesnej kulturze, służąc jej jako narzędzie do nowej konceptualizacji, kategoryzacji i wartościowania [por. Laskowska 2008: 219 -226], ale i rozszerzają repertuar polszczyzny konsumpcyjnej o nowe waloryzujące operatory (modulanty).

\section{Leksem gryfny w komunikacji górnośląskiej mikrowspólnoty}

Gwara jako substrat regionalny, podobnie jak socjolekt, ,,unifikuje proces interpretowania doświadczeń" [Grabias 1999: 55]. Będąc autoteliczną wartością, konsoliduje i magazynuje znamienny dla obszaru geograficznego repertuar językowy, kumuluje swoiste dla regionu wartości i kategorie znaczeniowe. Gwara, jaką posługują się na co dzień członkowie mikrowspólnoty, odtwarza subiektywne oceny, które zostały zakodowane w formie swoistej dla niej konceptualizacji rzeczywistości i uznawanych wartości. W ujęciu Haliny Pelcowej „gwara danego regionu wrasta w jego strukturę i go kształtuje, stając się elementem identyfikacji i wykładnikiem regionalnego lub lokalnego dziedzictwa kulturowego" [Pelcowa 2013: 219]. W takim ujęciu gwarę uznaje się za nośnik lokalnego i regionalnego dziedzictwa kulturowego [Pelcowa 2013: 219; Wronicz 2013: 231-237]. 
Obserwacja regionalnej (górnośląskiej) praktyki komunikacyjnojęzykowej nadawców perswazyjnych komunikatów obliguje do sformułowania tezy na temat szczególnej popularności leksemu gryfny, który wyzyskuje się nie tylko $\mathrm{w}$ rozmaitych gatunkach reklam promujących produkty czy usługi, ale i w nazewnictwie użytkowym. Leksem gryfny, jak wykazuje zgromadzony materiał analityczny, intencjonalnie wpisany w odpowiednie syntaktyczno-semantyczne struktury wypowiedzi, dowodzi nieograniczonych możliwości tworzenia perswazyjnych komunikatów, nakłaniających odbiorców do zakupu produktu bądź skorzystania z promocyjnej oferty.

Gryfny w gwarze śląskiej znaczy 'urodziwy, piękny, zgrabny’ [MSGP²: 79]; 'to określenie kogoś nie tylko ładnego fizycznie, ale też zręcznego, bystrego, zgrabnego w wykonywaniu jakichś czynności’ [NŚS: 44]; 'ładny' [SGŚ: 21]. Por. też: gryfny < niem. griffig = 'zgrabny - przystojny, urodziwy'; 'ładny, szykowny' [SGŚ: 104].

W codziennej komunikacji górnośląskiej mikrowspólnoty gryfnie używa się, by dokonać kategoryzacji - wyrażania opinii na temat wyglądu człowieka lub jego charakterystyki (por. Gryfno dziołcha/frela oraz męski odpowiednik Szwarny karlus); rzadziej stosuje się go do opisu wartości przedmiotów. W takiej prymarnej znaczeniowo roli leksemy gryfny i szwarny wyzyskano w reklamie Uniwersytetu Przyrodniczego, por. Yno gryfne frelki i szwarne karlusy $^{3}$ sztudyjujom na UPWr. Warto tu dodać, że w sloganie tym modulant yno służy jako operator wartościujący, który wspomaga proces wyróżnienia osób studiujących na wrocławskiej uczelni.

Jak wykazuje praktyka komunikacyjna twórców komercyjnych tekstów kultury, gryfny służy promocji atrakcyjnych dla lokalnych odbiorców produktów, miejsc czy obiektów świadczących usługi gastronomiczne i upiększające, sklepów oferujących rozmaity asortyment towarów, organizowanych imprez i projektów (rekreacyjnych, kulturalnych), stając się wszechobecnym składnikiem życia mikrowspólnoty oraz regionu. Wtórne wyzyskiwanie wartości tej regionalnej jednostki językowej przenosi się na sposoby generowania nowych znaczeń tekstowych, kontekstualnie wpisanych w zamysł kampanii, projektu i koncepcji marketingowych, podlegających zasadom konsumpcji. Próby aktualizacji oraz wydobycia wtórnych, rozszerzonych znaczeń leksemu gryfny oscylują wokół kilku przenikających się konsumpcyjnych strategii: a) wyróżnienia grupy docelowej lokalnych odbiorców oraz zamieszkiwanego

2 W dalszej części tekstu, przywołując definicje słownikowe, posługuję się skrótami ich źródeł; ich rozwinięcie znajdują się na końcu artykułu.

3 Pogrubienia, które zastosowano w obrębie przywoływanych przykładów, posłużyły w artykule do wyeksponowania wartościującej roli gwarowych leksemów lub ich kolokacji. 
przez nich regionu; b) charakterystyki i wartościowania produktu, usługi lub miejsca świadczącego usługę; c) określenia zakresu świadczonych usług; d) oceny stanu emocjonalnego odbiorcy poszukującego oferty (dotarcie do miejsca poszukiwań, do celu), w obrębie której dokonują się komercyjne procesy desemantyzacji, polegające na aktualizacji znaczenia znanego odbiorcom desygnatu, (kon)tekstualnie podporządkowanego intencji marketingowego modelu komunikacji. Przyjęte koncepcje i strategie marketingowe pozwalają wydobyć model wartościowania właściwy i paralelny dla danej wspólnoty kulturowo-językowej, a następnie przenieść go w obszar komercyjno-konsumpcyjny. Powstałe w ten sposób komunikaty nie tylko wyróżniają produkt, usługę, przedsięwzięcie, projekt, opisują bądź oceniają obiekt, ale też są rozpoznawalne i identyfikowane z regionem. Uznawane przez użytkowników lokalnego języka za swoje, wzmacniają więź mikrospołeczności.

Strategie te w formie szczegółowego opisu zaprezentowano poniżej.

\section{Gryfny jako modny komponent reklamowych przekształceń}

Zgromadzone przykłady reklam odsłaniają mechanizmy i sposoby semantycznego użycia gwarowego leksemu gryfny, którego znaczenie (kon)teksualnie wyzyskuje się (i w obrębie tego procesu również modyfikuje i rozszerza), by osiągnąć zakładany komercyjnie efekt. Opisane teksty obrazują tendencje do popularyzowania tych form $\mathrm{w}$ obrębie reklam różnych marek, promujących szeroki asortyment produktów o różnym przeznaczeniu oraz prezentujących rozmaite (też wyszukane) oferty świadczonych usług.

W pierwszym ze sloganów, stworzonym dla marki Coca-Cola, gwarą posłużono się jako „systemowym środkiem perswazji” [Awdiejew 2004: 71-80], por. Gryfnych Świont, Ślonzoki! Owa marketingowa tendencja do semantycznych przesunięć desygnatu ujawnia się tu w strategii wyróżnienia lokalnego odbiorcy (użycia kolektywnego etnonimu Ślazacy) oraz obszaru geograficznego, w którym miała miejsce kampania reklamowa. W spreparowanym komunikacie określenia gryfny używa się w celu wyeksponowania abstrakcyjnego desygnatu, jakim są święta Bożego Narodzenia ${ }^{4}$, które mogą być w pełni udane dzięki zakupowi promowanego napoju.

Zbliżone tendencje do przesunięć semantycznych ujawnia reklama promująca usługi firmy Liberty Ubezpieczenia. W spocie tym leksem gryfny, jako nadrzędny komponent wypowiedzi, wartościujący ofertę oraz odbiorcę, uległ

4 Por. „W procesach adaptacji stylistycznej może nastąpić zmiana hierarchii cechy, przez jej szczególne uwyraźnienie, a także zmiana typowych wykładników językowych" [Wojtak 2002: 324]. 
procesowi desemantyzacji, por. zwrot Wyrychtujemy ${ }^{5}$ Ci gryfny insiurans < Przygotujemy dla Ciebie piękne $\rightarrow$ [konotacja semantyczna $\rightarrow$ przesunięcie $] \rightarrow$ wspaniałe $\rightarrow$ najlepsze $\rightarrow$ perfekcyjne $\rightarrow$ odpowiadające twoim oczekiwaniom ubezpieczenie [por. Łuc 2019a]. Za istotne ogniwo perswazyjnego oddziaływania na odbiorcę uznać można w tym komercyjnym sformułowaniu operator tekstowy (zaimek dzierżawczy) $\mathrm{Ci}$, wzmacniający akt nobilitacji wyróżnionego za jego pomocą odbiorcy, który samoistnie ulega złudzeniu, że zamieszkiwany przez niego obszar geograficzny sprzyja konsumpcyjnej ofercie (działa na jego korzyść). Ponadto modulant tekstowy $C i$ sygnalizuje, że jednostkowo, indywidualnie oraz z szacunkiem traktuje się odbiorcę.

Zwrot do odbiorcy zastosowano też w reklamie radiowej Banku Spółdzielczego z Jastrzębia-Zdroju. W spocie tym prymarną funkcję pełni narrator, który zwracając się w sposób bezpośredni do lokalnego odbiorcy, eksponuje walory oferty:

Chcesz mieć pewny zysk? Kery by nie chcioł! Styknie, że skorzystosz ze oferty Banku Spółdzielczego we Jastrzymbiu-Zdroju. Jak mosz szwarno lokata, to mosz atrakcyjne warunki i pewność zysku. A jak potrzebujesz piniyndzy, to weź gryfny kredyt. Szybko decyzja i minimum formalności. Zaufej nojbliższym. Bank Spółdzielczy we Jastrzymbiu to ponad sto piytnoście lot tradycyji.

Składana oferta, w której następuje proces desemantyzacji znaczenia gryfny, przeniesionego do kategorii znaczeniowej 'zachwalanie i eksponowanie jakości oferty', odwołuje się do wartości tradycji i zaufania (por. zastosowaną formułę Zaufej najbliższym, czyli 'nam, lokalnemu bankowi').

W grupie omawianego typu reklam mieści się też spot niemieckiego koncernu motoryzacyjnego Volkswagen, opisujący jakość samochodu golf:

Chopy, pamiętocie sam ta maszina? Gryfno była choby szmaterlok. Łokna miała na sztrom, bez to szlo się niom asić przed kamratami. Wiela się zaś nie przełonaczyło. Gynoł do familiji i fest drapko. Yno kapka drokszo. Bo Golf je yno jedyn, ale mo mocka wariantów. Już od 59 tauzynów 900 złotych. Sprowdź, jak leko idzie cisnąć Volkswagenem.

W odsłonie tej reklamy narracyjnej [Łuc 2018b] warto zwrócić uwagę na kilka zabiegów perswazyjnych, wspomagających siłę illokucji wyzyskanego

5 Por. wyrychtować 'przygotować, naszykować' [SGŚ: 319]. 
leksemu gryfny. Gwarowy wykładnik posłużył tu jako komponent wartościującego porównania, dzięki któremu promuje się zwrotność i estetykę samochodu, por. Gryfno była choby szmaterlok ('piękna jak motyl - w znaczeniu lekka') oraz formuły szło się niom asić przed kamratami ('można się nią było pochwalić przed kolegami'), i jednocześnie podnosi prestiż społeczny przyszłego użytkownika. Owe kolokacje modnego leksemu z innymi jednostkami gwarowymi, jak również zbudowana na ich zasadzie linearna kompozycja komercyjnego tekstu potęgują jakość składanej oferty ponadczasowego samochodu.

Szczególną rolę gryfny odgrywa w perswazyjnym modelu komunikacji zastosowanym przez markę Gabriella (reklamującą rajstopy). Już sama sugestywna nazwa Gryfne Ślaskie waloryzuje produkt i jego jakość oraz region, który słynie ze swego kolorytu kulturowego, swoistych wartości, barwnych tradycji, obyczajów i symboliki. W umyśle odbiorcy nazwa ta ewokuje wiele pożądanych cech produktu, takich jak: unikatowość, oryginalność, atrakcyjność i trwałość. W treści tej reklamy promującej jakość produktu posłużono się też określeniem gryfny gyszynk $k^{6}$, sugerując, że ofiarowany komuś w prezencie produkt wysokiej jakości w pełni go zadowoli.

Producenci soków Pyrsk!, zachwalając jakość regionalnego produktu, wyzyskują gryfny, by dokonać gradacji wartościowania, por.: Jabłko najprzedniejszej zorty, miynta zerwano z krzoka i ślonski luft to je naszo receptura z richtik gryfny smak. Nojprzod poszelontej! Znamienną rolę w tym perswazyjnym komunikacie odgrywa zestawienie richtik gryfny ( $\rightarrow$ rzeczywiście, naprawdę smaczny), potwierdzające jakość promocji, potęgujące prawdziwość przekazu. Nie mniej istotną rolę przypisano też jednej z nazw produktu marki Pyrsk!!. Tworząc nazwę Gryfna cynamonka (napój zimowy z wyczuwalną nutą korzenną), twórcy komunikatu nie tylko odwołują się do naturalnej receptury, ale i gwarantują jakość produktu.

Przykładem reklamy zamykającej klasyfikacyjny rejestr komercyjnych wypowiedzi, w których gwarowy leksem gryfny pełni funkcję konsumpcyjnego wykładnika, jest spot reklamowy stworzony dla firmy Mercedes. W rekla-

6 Por. gyszynk < niem. Geschenk 'prezent, podarunek' [SGŚ: 106].

7 Nazwa Pyrsk! nie tylko przywołuje skojarzenia onomatopeiczne związane z procesem spożywania napoju, ale też ewokuje konotacje związane z kolejnym spotkaniem osoby żegnanej okrzykiem pyrsk; por. 'toast lub okrzyk pożegnalny’ [SGŚ: 239]; „Za najpiękniejsze śląskie słowo, chodzące za mną od dzieciństwa, uważam formę pożegnania - no to pyrsk ludkowie. Zasłyszane w audycjach, felietonach radiowych w latach 60.-70. Nie ma chyba lepszego pożegnania niż właśnie te słowa, dające nadzieję na nowe spotkanie i nową audycję" [NŚS: 97]. Dobór tej nazwy zakłada konsumpcyjną cykliczność $\rightarrow$ klient niejednokrotnie zakupi produkt. 
mie tej (o znamionach storytellingu) zaprezentowano historię górnika, który poszukuje salonu samochodowego, by utwierdzić się w przekonaniu na temat jakości i estetyki nowego modelu samochodu (warto tu dodać, że ofertę na ów atrakcyjny model stworzono specjalnie dla górników). Gdy mężczyzna dociera do celu (i stoi pod sosnowieckim salonem), puentuje swoją podróż słowami: I jużech je na miejscu... Gryfnie... Kontekstualnie wpisany w narrację reklamową leksem gryfnie w wypowiedzi reklamowej narratora posłużył do określenia jego euforii wywołanej faktem dotarcia do miejsca poszukiwań oraz nowoczesnością i wielkością poszukiwanego obiektu (sosnowieckiego salonu samochodowego). W tym kontekście określenie gryfnie pełni funkcję przedstawieniową, ekspresywną i aluzyjną.

Zaprezentowane przykłady reklam, w których zastosowano strategię perswazyjnej aksjologizacji leksemu gryfny, pokazują, że użyty w jej obrębie powtarzalny mechanizm przesunięcia znaczeniowego prowadzi do rozchwiania semantycznego na poziomie konotacji i poszerzenia znaczenia wyrazu determinowanego przez właściwości subkodu gwarowego. Z drugiej zaś strony owa strategia ułatwia przywołanie motywacji powiązanej z kreacją wypowiedzi oraz usytuowanie gwarowej jednostki językowej w dowolnym kontekście ${ }^{8}$ przywołującym określony (zakładany przez nadawcę) efektywny typ komercyjnych znaczeń. Można zatem przyjąć, że leksem gryfny, utrwalając się w repertuarze polszczyzny konsumpcyjnej, ulega generalizacji znaczeniowej, stając się polisemem i swego rodzaju ozdobnikiem semantycznym.

\section{Gryfny jako komercyjny wykładnik chrematonimii użytkowej}

Uwzględniając kryterium częstotliwości wyzyskiwania leksemów gwarowych jako komponentów nazw użytkowych, możemy również mówić (podobnie jak w wypadku analizowanych wcześniej tekstów reklam) o pewnej seryjności w kreowaniu modelu wpisującego się w ramy regionalnej mody nazewniczej. Ta powtarzalność odnosi się do użycia leksemu gryfny jako składnika struktury onimicznej miejskich obiektów handlowych, gastronomicznych, usługowych: sklepów, restauracji, firm, nazw promujących regionalne imprezy, festiwale, konkursy, warsztaty i projekty kulturalno-oświatowe oraz nazw placówek oświatowych. Zebrane przykłady komercyjnych nazw pokazują, że leksem gryfny, pojawiając się wielofunkcyjnie i wielosyntaktycznie, wypełnia ich struktury.

Artur Gałkowski w rozprawie Chrematonimy w funkcji kulturowo-użytkowej..., odwołując się do szerokiej definicji chrematonimu, zaproponował

8 Ronald Langacker dowodzi, że zmiana kontekstu oznacza modyfikację znaczenia wyrazu [Langacker 1987: 405]. 
określenie chrematonimia użytkowa, w której obrębie wytypował trzy podkategorie nazewnicze. Do pierwszej z nich zaliczył chrematonimię marketingowa $(\mathrm{ChM})$, zajmującą się nazwami firm oraz całym marketingiem powiązanym z procesami promocji. Do drugiej grupy autor tej trychotomicznej koncepcji zakwalifikował chrematonimię społecznościowa ${ }^{9}(\mathrm{ChS})$, obejmującą nazwy stowarzyszeń, fundacji, organizacji, instytucji religijnych i parareligijnych, do trzeciej zaś - chrematonimię ideacyjna (ChI) - nazwy wydarzeń artystycznych, imprez rozrywkowych, konkursów, festiwali, inicjatyw, programów i akcji społecznych [Gałkowski 2011: 61-229].

W obrębie nazewniczych kreacji z udziałem modnego wykładnika waloryzacji gryfny wyodrębniają się dwie kategorie chrematonimów: nazwy obiektów usługowo-handlowych i nazwy lokali gastronomicznych. Zaklasyfikowane przez Gałkowskiego do grupy nazw marketingowych twory promują sklepy spożywcze, meblowe i odzieżowe, por.: Gryfny Kraiczek ${ }^{10}$, Gryfny Mebel, Gryfny Szrank, a rozbudowana konstrukcja onimiczna Fest Gryfny Szrank reklamuje sklep z odzieżą używaną. W nazwie Fest Gryfny Szrank w sposób gradacyjny wyzyskano dwuskładnikowy operator fest gryfny (w znaczeniu 'bardzo piękny, niepowtarzalny, unikatowy, wyjątkowy'), rozbudowujący repertuar polszczyzny konsumpcyjnej. Na podobnej zasadzie stworzono też struktury będące wizytówką punktów świadczących usługi upiększające, por: Gryfny Chop ${ }^{11}$ (fryzjerstwo i kosmetyka), Gryfno Frelka (salon kosmetyczny), Gryfno $W$ la $^{12}$ (salon fryzjerski). Owe chrematonimy użytkowe, firmując jakość świadczonych usług, eksponują podmiotowość klienta; w dwóch z nich - Gryfny Chop i Gryfno Frelka - leksem gwarowy wyzyskano zgodnie z jego pierwotnym, regionalnym znaczeniem (służy określeniu cech, charakterystyce osób).

Przy użyciu modnego leksemu gryfny wartościowano też inne obiekty przestrzeni Górnego Śląska, przywołując odpowiednie konotacje semantyczne, por.: Gryfno Karczma ('tu można dobrze zjeść), pub Gryfna Lama ('znajdziesz tu egzotyczne napoje') i Pracownia Florystyczna Gryfno Bluma ${ }^{13}$ ('tworzymy z pięknych kwiatów wyjątkowe wiązanki').

Nazwą Gryfnie komponowaną poprzez proprializację (bez kreacji formalnojęzykowej) posłużono się, by promować wśród młodych ludzi śląskie dzie-

9 Nazwy te utrwalone w świadomości społecznej, choć tworzone są okazjonalnie, trwale wpisują się w kulturę konsumpcyjną [Gałkowski 2011a: 52-53].

10 Por. kraiczek 'kromka chleba' [SGŚ: 145]; por. też w gwarze śląskiej iść kraiczkiem, gdzie kraiczek to 'skraj drogi, pobocze'.

11 Por. chop 'mężczyzna, mąż' [SGŚ: 55].

12 Por. wela $<$ niem. Welle 'lok na głowie' [SGŚ: 308].

13 Por. blumy< niem. Blumen 'kwiaty' [SGŚ: 40]. 
dzictwo kulturowe. Ową motywację można wyczytać z wypowiedzi Krzysztofa Rokseli, założyciela portalu Gryfnie i właściciela sklepu internetowego - najbardziej rozpoznawalnej marki na Śląsku, por.:

Gwara znów staje się powoli modna. Młodzi ludzie mają potrzebę określenia swojej tożsamości. Sam pochodzę z Małopolski, więc nigdy nie będę mówił dobrze w gwarze. Żałuje, bo uważam, że jest ona naprawdę piękna. Myślę, że to od naszego pokolenia zależy, czy przetrwa w takiej postaci czy będzie tylko ornamentem, jakimś odblaskiem przeszłości [...]. To co w naszej gōdce jest najważniejsze, to że język kreuje rzeczywistośćc ${ }^{14}$.

Grupę chrematonimów ideacyjnych tworzonych przy współudziale operatora gwarowego gryfny reprezentują nazwy promujące regionalne imprezy, festiwale, konkursy, warsztaty i projekty edukacyjne, będące konkretnymi propozycjami uczestnictwa w wydarzeniach i inicjatywach kulturalnych spędzenia czasu wolnego oraz promowania talentów. W nazwach tych leksem gwarowy (jako element kolokacji z innymi jednostkami językowymi) umożliwił kreację nazw o charakterze metaforycznym, por. struktury typu: Gryfny Bieg, Gryfny Bieg Kolorów reklamujące akcje organizowane w ramach Parkowej Korony Biegów oraz Gryfny happening gitarowy, którego atrakcją było bicie rekordu gitarowego polegającego na wspólnym wykonaniu śląskiego evergreenu, utworu Whisky zespołu Dżem.

Chrematonimy społecznościowe reprezentuje nazwa placówki oświatowej w Studzienicach, Zespół Szkolno-Przedszkolny Gryfne Bajtle ${ }^{15}$, zaś do grupy chrematonimów ideacyjnych zaliczyć można nazwę wystawy zorganizowanej w Parku Śląskim w Chorzowie (por. Gryfne klocki), w której leksem gwarowy służy ocenie i określeniu obiektu.

Przywołane tu przykłady nazw użytkowych pokazują, że w konsumpcyjnej semantyce, związanej ze sposobami łączenia atrakcyjnego dla polszczyzny konsumpcyjnej desygnatu gwarowego gryfny z innymi (również wywodzącymi się z polszczyzny ogólnej) jednostkami języka, określenie to służy charakterystyce obiektu, ocenie oferty i wartościowaniu świadczonych usług. Owe efekty konsumpcyjne uzyskuje się przez przeniesienie znaczeń podlegające schematowi: opis istoty ludzkiej - podmiotu translokowany na obiekt lub ofertę $\rightarrow$ nowe (rozszerzone) znaczenie $\rightarrow$ atrakcyjny, interesujacy, modny,

14 https://natemat.pl/27723, gryfnie-czyli-pieknie-slask-odzyskuje-swoja-mowe-gwara-znoww-modzie [dostęp: 28 stycznia 2019].

15 Por. bajtel 'maluch, chłopczyk' [NŚS: 12]. 
oryginalny, piękny, wspaniaty, wyjątkowy. W ten sposób dokonuje się proces przekształcania regionalnego zasobu leksykalnego i odkrywają się marketingowe tendencje do semantycznych przesunięć desygnatu. Proces ten, jak podpowiada Bogusław Dunaj, polega na

zmianie zakresu użycia i [...] statusu niektórych wyrazów o użyciu ograniczonym stylowo. Przejawia się to w przenoszeniu wyrazów z jednej odmiany języka do innej, szczególnie z odmiany potocznej, odmian środowiskowych i zawodowych do polszczyzny ogólnej [...]. [Dunaj 2000: 29]

Zaprezentowany materiał nazewniczy dowodzi, że opisywane zjawisko nazewnicze ma coraz większy zasięg. Poświadcza to częstotliwość pojawiania się wyekscerpowanych chrematonimów użytkowych, których prymarnym wykładnikiem formalnym jest dobierana seryjnie jednostka językowa służąca nadawcom jako modny komercyjny komponent onimiczny. W takim komunikacyjnym kontekście tendencje związane z powtarzalną próbą nominacji nazewniczych uznać można za przejaw onimicznej mody na składniki wartościowania [por. Jaracz 2002: 177-185; Młynarczyk 2016: 117-125], biorąc zaś pod uwagę seryjność powstających typów nazewniczych, można mówić o swoistej irradiacji onomastycznej [Młynarczyk 2016: 123].

\section{Wnioski}

Nowa odmiana języka - polszczyzna konsumpcyjna, której podstawową oś konstrukcyjną wyznacza postawa mieć, nieprzemiennie ewoluuje, a jej elementy ekspansywnie wkraczają w różne sfery życia. Współorganizowana przez przymiotniki waloryzujące i przysłówki oraz inne modne modulanty tekstowe wartościujące wypowiedź (przekaz) - jak wykazał opis wybranej do oglądu problematyki - rozszerza swój repertuar o nowe tworzywo, którym jest gwara śląska.

Zaprezentowany materiał reklamowy i onimiczny dowodzi, że skutecznymi sposobami oddziaływania na lokalnych (regionalnych) użytkowników języka stają się odwołania do ich subkodu, uwzględniane w aktach tworzenia perswazyjnych konstrukcji werbalnych. Cecha dystynktywna gwary górnośląskiej uznana przez nadawców jako atrakcyjne narzędzie do kreacji wyszukanych komunikatów, wewnątrz których dokonuje się proces desemantyzacji (przesunięć semantycznych) leksemu gryfny, to skuteczny perswazyjny środek oddziaływania na regionalnych odbiorców. Przywołane przykłady pozwalają też stwierdzić, że semantycznie i formalno-funkcjonalnie połączenia leksykalne nie tylko mają moc waloryzacji, ale też obrazują rozwój języka polszczyzny 
konsumpcyjnej i zubożenie semantyki gwarowej. Potwierdzenia tego stanu rzeczy można doszukać się w stanowisku Ewy Kołodziejek, która podkreśla, że moda językowa, choć efemeryczna,

powoduje istotne zmiany zarówno w strukturze słownej języka, jak i jego strukturze semantycznej: wyrazy nadużywane [...] dominują nad innymi w ciągach synonimicznych [...], rozszerzają lub zmieniają znaczenia i z natręta słownego stają się elementem organizującym semantyczną przestrzeń języka. [Kołodziejek 2006: 227]

wbrew oczekiwaniom jego użytkowników - nie wzbogaca środków wyrazu, lecz przeciwnie, zawęża je i zuboża. [Kołodziejek 2006: 321]

Owa tendencja komunikacyjnojęzykowa wybrzmiewa też w słowach Władysława Lubasia:

Przekonanie o wyjątkowo pozytywnej roli aksjologicznej potocyzmów [...] w dużym stopniu okazuje się złudne, ponieważ składniki odmiany potocznej z powodu [...] uproszczonego obrazu świata widzianego przez ograniczoną poznawczo siatkę semantyczną słownictwa koncentrującego się zwykle na oglądowości, a nie na abstrakcyjności [...] dają możliwość przemycania nieprawdy lub półprawdy i w końcu otwierają szeroko wrota manipulacji. [Lubaś 2000: 89]

Konkludując rozważania na temat roli i znaczenia gwarowego leksemu gryfny w repertuarze polszczyzny konsumpcyjnej oraz jego popularyzacji (częstotliwości użyć) w tekstach reklamowych i nazewnictwie użytkowym, można stwierdzić, że ów komponent traktowany jest przez twórców komercyjnych komunikatów jako strukturalny ozdobnik, uniwersalny wabik aksjologiczny oraz substytut semantyczny; mimo swej funkcjonalnej jednostkowości w strategiach komercyjnych uniwersalnie współtworzy i organizuje komunikacyjną przestrzeń kultury ponowoczesnej, dopełniając kontekstualnie perswazyjne funkcje. 


\section{Bibliografia}

\section{Stowniki}

MSGŚ - Jadwiga Wronicz, red., Mały słownik gwar polskich, Wydawnictwo Lexis, Kraków 2010.

NŚS - Dariusz Kortko, Leszek Jodliński, red., Antologia. Najpiękniejsze śląskie słowa, Muzeum Śląskie, Katowice 2010.

SGŚ - Barbara i Adam Podgórscy, Słownik gwar śląskich. Godómy po naszymu, czyli po Śląsk, Wydawnictwo KOS, Katowice 2008.

Literatura

Awdiejew Aleksy (2004), Systemowe środki perswazji, w: Manipulacja w języku, red. Piotr Krzyżanowski, Paweł Nowak, Wydawnictwo UMCS, Lublin, s. 71-80.

Dunaj Bogusław (2000), O stanie współczesnej polszczyzny, w: Język a komunikacja 1: Zbiór referatów z konferencji „Język trzeciego tysiąclecia”. Kraków 2-4 marca 2000, red. Grzegorz Szpila, Krakowskie Towarzystwo Popularyzowania Wiedzy o Komunikacji Językowej „Tertium”, Kraków, s. 25-34.

Gałkowski Artur (2011), Chrematonimy w funkcji kulturowo-użytkowej. Onomastyczne studium porównawcze na materiale polskim, włoskim, francuskim, wyd. 2, Wydawnictwo UŁ, Łódź.

Grabias Stanisław (1999), Uwagi o wartościowaniu w socjolektach, w: Wartościowanie w dyskursie edukacyjnym, red. Jan Ożdżyński, Sławomir Śniatkowski, Wydawnictwo Naukowe Akademii Pedagogicznej, Kraków (Studia Logopedyczne, t. 5), s. 53-67.

Jaracz Małgorzata (2002), Uwagi na temat mody językowej w wybranych systemach nazw własnych, w: Moda jako problem lingwistyczny, red. Krystyna Wojtczuk, Wydawnictwo Akademii Podlaskiej, Siedlce, s. 177-287.

Kita Małgorzata (2001), Język potoczny jako język bliskości, w: Język w komunikacji, t. 1, red. Grażyna Habrajska, Wydawnictwo AHE, Łódź, s. 170-175.

Kniagininowa Maria, Pisarek Walery (1965), Język w reklamie pasowej, w: Reklama prasowa. Zawartość, język, odbiór, red. Paweł Dubiel i in., Wydawnictwo UJ, Kraków.

Kołodziejek Ewa (2006), Festiwal radosnych zakupów - moda językowa na tle wspótczesnych zmian kulturowych, w: W kręgu polszczyzny dawnej i współczesnej. Księga ofiarowana dr. hab. Kazimierzowi Długoszowi, profesorowi Uniwersytetu Szczecińskiego, red. Ewa Kołodziejek, Wydawnictwo Naukowe US, Szczecin 2006, s. 219-231.

Langacker Ronald (1987), Foundations of Cognitive, Stanford University Press, Stanford. 
Laskowska Ewa (2008), Wartościowanie jako środek perswazji, w: Język, społeczeństwo, wartości, red. Ewa Laskowska, Iwona Benenowska, Małgorzata Jaracz, Wydawnictwo UKW, Bydgoszcz, s. 219-226.

Loewe Iwona (1997), Reklama zaprasza do gry, czyli o tym, jak i o co się gra w tekście reklamowym, w: Gry w języku, literaturze i kulturze, red. Ewa Jędrzejko, Urszula Żydek-Bednarczuk, Wydawnictwo Energia, Warszawa, s. 99-110.

Lubaś Władysław (2000), Słownictwo potoczne w mediach, w: Język w mediach masowych, red. Jerzy Bralczyk, Katarzyna Mosiołek-Kłosińska, Wydawnictwo Upowszechnianie Nauki-Oświata „UN-O”, Warszawa, s. 83-95.

Łabądź Justyna Weronika (2019), Gryfnie - czyli ładnie i pięknie o Śląsku po Ślasku, „2B Style” grudzień '18 - styczeń '19, s. 76-79.

Łuc Izabela (2010), Współczesne gry komunikacyjnojęzykowe, Wydawnictwo UŚ, Katowice.

Łuc Izabela (2018), Komercyjna waloryzacja gwary śląskiej w reklamowej narracji, „Białostockie Archiwum Językowe”, nr 18, s. 139-164.

Łuc Izabela (2019a), Chrematonimy marketingowe o podstawie gwarowej jako nośnik wartościowania przestrzeni Górnego Ślaska, w: Nazwy własne w języku, literaturze i kulturze. Księga Jubileuszowa dedykowana Profesor Zofii Abramowicz, red. Anna Rygorowicz-Kuźma, Krzysztof Rutkowski, Wydawnictwo Uniwersytetu w Białymstoku, Białystok 2019, s. 387-417.

Łuc Izabela (2019b), Gwara śląska jako wartościujący determinant reklamowy, „Słowo. Studia językoznawcze”, nr 9 [w druku].

Młynarczyk Ewa (2016), Modne nazwy firmowe (na przykładzie nazw salonów kosmetycznych), „Poznańskie Spotkania Językoznawcze”, t. 32, s. 117-125.

Ożóg Kazimierz (2004), Polszczyzna przełomu XX i XXI wieku. Wybrane zagadnienia, wyd. 3, Stowarzyszenie Literacko-Artystyczne „Fraza”, Rzeszów.

Pelcowa Halina (2013), Gwara jako nośnik lokalnego i regionalnego dziedzictwa kulturowego, w: Niematerialne dziedzictwo kulturowe: źródła-wartości-ochrona, red. Jan Adamowski, Katarzyna Smyk, Wydawnictwo UMCS, Lublin-Warszawa, s. 219-229.

Pisarek Walery (1993), Słowa na usługach reklamy w Polsce (1962-1993), „Zeszyty Prasoznawcze", nr 3-4, s. 65-77.

Rutkowski Mariusz (2012), Słownik metafor i konotacji nazw własnych, Uniwersytet Warmińsko-Mazurski, Olsztyn.

Storey John (2003), Studia kulturowe i badania kultury popularnej. Teorie i metody, przeł. Janusz Barański, Wydawnictwo UJ, Kraków.

Szlendak Tomasz, Pietrowicz Krzysztof (2005), Kultura konsumpcji jako kultura wyzwolenia? Między krytyka konsumeryzmu a społeczeństwem opartym na modzie, „Kultura i Społeczeństwo”, t. 49, nr 3, s. 85-108. 
Wierzbicka Anna (2008), Slogany reklamowe uczelni wyższych - marketing czy/i kreowanie nowej rzeczywistości?, w: Język w marketingu, red. K. Michalewski, Wydawnictwo UŁ, Łódź 2008, s. 292-340.

Wojtak Maria (2002), Potoczność w tekstach prasowych, w: Język trzeciego tysiaclecia, t. 2: Nowe oblicza komunikacji we wspótczesnej polszczyźnie, red. Grzegorz Szpila, Krakowskie Towarzystwo Popularyzowania Wiedzy o Komunikacji Językowej „Tertium”, Kraków, s. 323-334.

Wronicz Jadwiga (2013), Gwara jako element regionalnego dziedzictwa kulturowego, w: Niematerialne dziedzictwo kulturowe: źródła - wartości - ochrona, red. Jan Adamowski, Katarzyna Smyk, Wydawnictwo UMCS, Lublin-Warszawa, s. 231-237.

\section{Strony internetowe}

https://natemat.pl/27723, gryfnie-czyli-pieknie-slask-odzyskuje-swoja-mowe-gwaraznow-w-modzie [dostęp: 28 stycznia 2019].

Izabela Łuc

\section{The dialectal lexeme gryfny as a fashionable component of Polish language of consumption}

The object of the analysis is the way of creating commercial utterances and functional names in which the formal indicator is the dialectal lexeme gryfnie recognized as a fashionable component of Polish language of consumption. According to the communicative practice of the creators of cultural texts, the use of the gryfny component valorizes products, identifies service objects, assesses offers and highlights the speakers of the language living in the Upper Silesia region. The analytical material coming from the advertisements spread by media and on the Internet was described from the perspective of cultural linguistics and pragmalinguistics. The references to cognitive conception of meaning fields were made taking into account the appropriate methodological solutions and the complex polisystem of commercial conditions.

KEYWORDS: language fashion, dialect, Polish language of consumption, Upper Silesia.

dr hab. Izabela Luc - Zakład Dydaktyki i Pedagogiki Wczesnoszkolnej i Przedszkolnej Uniwersytetu Śląskiego w Katowicach; zainteresowania naukowe: pragmatyka językowa, polszczyzna konsumpcyjna, nowe zjawiska w języku i kulturze języka, onomastyka (w tym literacka). 